\title{
EDAPHIC INVERTEBRATE DIVERSITY AROUND THE RESERVOIR OF A SMALL HYDROELECTRIC POWER STATION IN SOUTHERN BRAZIL
}

\section{Diversidade de invertebrados edáficos ao redor do reservatório de uma pequena central hidrelétrica no Sul do Brasil}

\author{
https://doi.org/10.18593/eba.28131 \\ Recebido em 21 de julho de 2021 | Aceito em 27 de outubro de 2021.
}

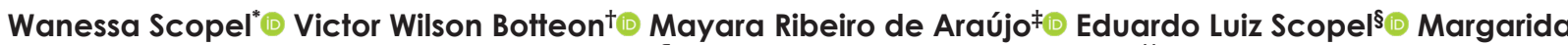

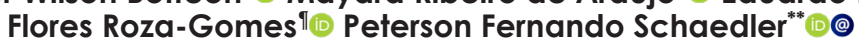

\footnotetext{
Doutora em Entomologia Agrícola pela Escola Superior de Agricultura Luiz de Queiroz (Esalq), Universidade de São Paulo (USP). Biólogo e Mestre em Ciências pelo Centro de Energia Nuclear na Agricultura (Cena), Universidade de São Paulo (USP).

Doutora em Entomologia Agrícola pela Escola Superior de Agricultura Luiz de Queiroz (ESALQ), Universidade de São Paulo (USP).

Engenheiro Agrônomo e Especialista em Segurança do Trabalho pela Universidade do Oeste de Santa Catarina (Unoesc).

" Doutora em Produção Vegetal pela Universidade do Passo Fundo (UPF) e Professora da Universidade do Oeste de Santa Catarina (Unoesc).

* Mestre em Ciências Ambientais pela Universidade Comunitária da Região de Chapecó (Unochapeco) e Professor da Universidade do Oeste de Santa Catarina (Unoesc); https://orcid.org/0000-0003-4113-0955; peterson.schaedler@unoesc.edu.br
}

Abstract: To meet the growing demand for electricity, considerable effort has been invested in the construction of hydroelectric stations in Brazil. The environmental impacts caused by these projects have been significant, especially on fauna. To evaluate the biodiversity of edaphic invertebrates, a study was performed in an area surrounding a small hydroelectric station of Flor do Sertão, in the Santa Catarina state, Brazil, covering three distances (5, 15 and 30 meters) from the flooded region of the reservoir. From December 2010 to June 2011 , surveys of edaphic invertebrates were performed by pitfall traps. The invertebrates collected at each distance were compared and their diversity was calculated through Hill numbers. The dynamics were analyzed through the Shannon index exponential and the inverse Simpson index, and correlated climatic variables to invertebrate diversity. A total of 14,074 specimens were collected from 24 taxonomic groups (Order). The analyses according to size and sample coverage showed few differences in invertebrate diversity between the distances. Values of richness and diversity of common groups are similar for all distances. There is a trend decrease in diversity dynamics for common individuals, with a strong decline in June. The diversity of edaphic invertebrates exhibited high correlation with temperature and no correlation with pluviosity.

Keywords: Biodiversity. Environmental impact. Pitfall traps. Hill numbers.

@ Autor correspondente: Mestre em Ciências Ambientais pela Universidade Comunitária da Região de Chapecó (Unochapeco) e Professor da Universidade do Oeste de Santa Catarina (Unoesc); https://orcid.org/0000-0003-41 13-0955; peterson.schaedler@unoesc.edu.br 
Resumo: Visando atender à crescente demanda de energia elétrica, tem-se investido consideravelmente na construção de usinas hidrelétricas no Brasil. O impacto ambiental causado por esses empreendimentos tem sido significativos, especialmente sobre a fauna terrestre. Para avaliar a diversidade de invertebrados edáficos, realizou-se um estudo em área próxima ao reservatório da pequena central hidrelétrica de Flor do Sertão, Santa Catarina, Brasil, contemplando três distâncias (5, 15 e 30 metros) da região alagada. Durante os meses de dezembro de 2010 a junho de 2011 foram realizados levantamentos de invertebrados edáficos com armadilhas de solo do tipo Pitfall. A diversidade de invertebrados coletados em cada distância foi comparada e calculada pelos números de Hill. A dinâmica durante o período de coleta foi estudada pelo exponencial do índice Shannon e inverso do índice de Simpson, e correlacionadas variáveis climáticas à diversidade de invertebrados. Foram coletados 14.074 indivíduos de 24 grupos taxonômicos (Ordem). As análises em função do tamanho e cobertura amostral mostraram poucas diferenças na diversidade de invertebrados entre as distâncias. Valores de riqueza e diversidade de grupos comuns são semelhantes para todas as distâncias. Há tendência de redução na dinâmica de diversidade de indivíduos comuns, com um acentuado declínio em junho. A diversidade de invertebrados do solo apresentou alta correlação com as temperaturas e não houve correlação com a pluviosidade.

Palavras-chave: Biodiversidade. Impacto ambiental. Pitfall traps. Números de Hill.

\section{INTRODUCTION}

Due to the increasing demand for renewable energy in Brazil, investment in hydroelectric stations has increased considerably in recent decades, possibly resulting in significant environmental impacts, especially on biodiversity ${ }^{1}$. Small hydroelectric stations are defined as minor facilities with an installed capacity between 10-30 MW and total reservoir area of $\leq 3.0 \mathrm{~km}^{2,3}$, and flooded areas surrounding its reservoir can impact edaphic fauna.

Edaphic fauna comprises a great variety of invertebrate organisms that inhabit the soil ${ }^{4}$ and are extremely important in decomposing organic material, maintaining soil fertility, cycling nutrients, regulating biological processes and establishing several relations at different levels with microorganisms ${ }^{5,6}$. Since they represent a diverse group of great ecological and economic importance, given their involvement in several environmental processes, soil fauna can be considered biological indicators which allow the monitoring of environmental changes caused by anthropic activities ${ }^{7-10}$.
The influence of environmental impacts induces a faster response on the edaphic fauna than in other soil attributes ${ }^{11}$. Unfortunately, studies of invertebrate fauna are still scarce in Brazil and have low applicability in concrete cases ${ }^{12}$. According to Rovedder et al. ${ }^{3}$, an important feature of the soil is the vast and complex relationship existing between its organisms and how its fauna plays an important role in maintaining the food chain and energy flow in the ecosystem.

Losses in the biological diversity of the soil would result in immeasurable environmental damage. The resulting information could allow the comparison between different areas of interest for appropriate management decisions, once anthropogenic activities can drastically alter ecosystem structure, possibly leading to biodiversity decline and even culminating in the extinction of some species ${ }^{14-17}$. Therefore, it is fundamental to know the area of study to evaluate the losses of animals and habitats toward applying an effective management program for species conservation $^{18}$.

Areas around hydroelectric power stations can be directly or indirectly impacted by the effects of activities from implementing and 
operating these enterprises, which transform the environment ${ }^{19,20}$. In this context, the objective of this study was to investigate the influence on different distances from the flooded region and the effects of meteorological variables on the edaphic invertebrate diversity in the area of a small hydroelectric station.

\section{MATERIALS AND METHODS}

\subsection{SAMPLING AREA}

The study was performed from December 2010 to June 2011 in areas around the reservoir of the small hydroelectric power station of the Flor

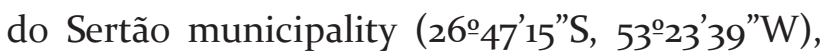
located in the western region of the Santa Catarina state, Brazil (Figure 1). The size of the studied area comprised one hectare, and the technical director of the management company of the small hydroelectric station, Mr. João Carlos Floss, accompanied the collections in the area during the entirety of the study.

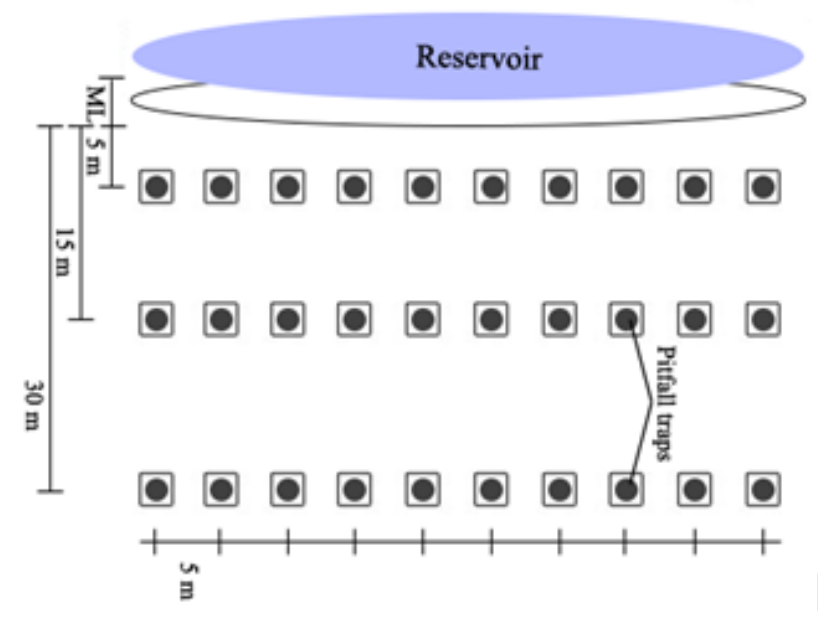

Figure 1 - Scheme of the experiment design demonstrating the maximum limit of the reservoir (ML), the three collection lines and respective distances of 5,15 and 30 meters from the reservoir.
The climate in the region is subtropical (Cfa according to Köppen-Geiger climate classification system $)^{21}$, with an annual average temperature ranging from $17^{\circ} \mathrm{C}$ to $28^{\circ} \mathrm{C}$, with an average annual rainfall of 1700 to $1900 \mathrm{~mm}$. The altitude is $265 \mathrm{~m}$ above sea level. The Permanent Preservation Area (APP) of the reservoir is constituted by arboreal vegetation in initial and middle stages of natural regeneration and of anthropic areas of different forms, including nearby residences, and some areas dominated by grasses, where the experiment was established.

The meteorological data (pluviosity and temperature) were obtained from the weather station of Centro de Informações de Recursos Ambientais e de Hidrometeorologia de Santa Catarina (Ciram) of Empresa de Pesquisa Agropecuária e Extensão Rural de Santa Catarina (Epagri) located in São Miguel do Oeste, Brazil, approximately $18 \mathrm{~km}$ from Flor do Sertão. These values are presented in Table 1.

Table 1 - Meteorological data from December 2010 to June 2011 in the region of the small hydroelectric station of Flor do Sertão, Brazil

\begin{tabular}{|c|c|c|c|c|}
\hline $\begin{array}{l}\text { Month/ } \\
\text { Year }\end{array}$ & $\begin{array}{l}\text { Pluviosity } \\
\quad(\mathrm{mm})\end{array}$ & $\begin{array}{l}\text { Min. } \\
\text { Temp. } \\
\left({ }^{\circ} \mathrm{C}\right)\end{array}$ & $\begin{array}{l}\text { Max. } \\
\text { Temp. } \\
(\stackrel{\circ}{ } \text { C })\end{array}$ & $\begin{array}{c}\text { Mean } \\
\text { Temp } \\
(\text { oㄷ) }\end{array}$ \\
\hline $\mathrm{Dec} / 2010$ & 435 & $7 \cdot 4$ & 32 & 22.46 \\
\hline Jan/2011 & 258 & 16.6 & 32.8 & 23.88 \\
\hline $\mathrm{Feb} / 2011$ & $217 \cdot 4$ & 16.4 & 30.8 & 23.09 \\
\hline Mar/2011 & 264.6 & 14.2 & 30.6 & 22.11 \\
\hline Apr/2011 & 174.2 & 11.8 & 30 & 20.09 \\
\hline May/2011 & 72.4 & 6.8 & $27 \cdot 4$ & 16.35 \\
\hline Jun/2011 & 288.3 & -1.2 & 26.2 & 13.86 \\
\hline
\end{tabular}

\subsection{COLLECTION SETTINGS}

Pitfall traps were installed at different distances from the reservoir following the procedures of Aquino et al. ${ }^{22}$. The samples were 
spaced in line at 5, 15 and $30 \mathrm{~m}$ from the maximum filling level of the reservoir (the limit reached by the reservoir during rainy season) according to Figure 1. Each line was arranged with ten samples at every five meters, totalizing 30 samples per collection. The traps remained set for a period of five days, and afterwards checked to collect the edaphic invertebrates captured. Seven collections were performed during the entire experiment period, one per month.

The traps were installed in straight lines with the aid of a tape measure and a compass, and were marked with wood stakes to identify their precise location. Pitfall traps consisted of cut PET bottles coupled with a $500 \mathrm{~mL}$ plastic cup buried at the ground level, protected with PVC plates against rain. The cup contained a $70 \%$ ethanol solution with three drops of neutral detergent to break the water surface tension.

The traps were installed just over 3 years after the plant's operations began (July 28, 2007).

\subsection{DATA COLLECTION}

Edaphic invertebrates were collected from pitfall traps throughout the experiment period, conditioned in plastic bottles (500 $\mathrm{mL}$ ) and transported to the Zoology Laboratory of Universidade do Oeste de Santa Catarina (Unoesc) in the São Miguel do Oeste campus, Brazil, for adequate identification. Samples were sort by morphotype. Morphological characteristics of invertebrates were examined using a stereomicroscope, and the taxonomic identification at the order level at least was performed by dichotomous keys ${ }^{23,24}$. Araújo and Ribeiro $^{25}$ emphasized that studies involving taxonomic survey of soil fauna are often restricted to the order level due to the complexity, high biodiversity and lack of specific studies on this topic. After identification and quantification of the invertebrate fauna, samples were stored in vials containing $70 \%$ ethanol.

\subsection{DATA ANALYSIS}

Analyses based on Hill numbers were performed to measure invertebrate diversity at the three distances from the small hydroelectric station reservoir at Flor do Sertão, in the Santa Catarina state. These numbers are parameters of order used to represent the diversity of individuals at a particular location. Three widely used measures of diversity are included in this order: groups richness $(\mathrm{q}=0)$; Shannon diversity, which is calculated by $\log (q=1)$; and Simpson diversity $(q=2)^{26}$. The measures are sensitive to the abundance of groups. The first also accounts for the groups, regardless of their relative abundance, while the second counts individuals equally - that is, groups in proportion to their abundance - and is interpreted as the effective number of common groups. Lastly, the third takes into account the effective number of dominant groups, excluding the others ${ }^{27}$. Therefore, the iNEXT software package $\mathrm{R}^{28}$ was used to estimate the rarefaction and extrapolation curves for $\mathrm{q}=0,1$ and 2 based on the abundance data of individuals, comparing collection distances. Hill numbers allow for more robust and detailed statistical comparisons between samples ${ }^{26}$.

Thedynamics of edaphic invertebrates were studied throughout the collection period using the Shannon index exponential and the inverse Simpson index, which correspond to $\mathrm{q}=1$ and $\mathrm{q}=\mathbf{2}$ respectively. These indexes were calculated using PAST software 1.73 (Paleontological Statistics) ${ }^{29}$. Furthermore, the diversity was correlated to 
climatic variables of temperature and pluviosity of the monitoring period.

\section{RESULTS}

A total of 14,074 specimens from 24 taxonomic groups were collected during this study (Table 2). Collembola, Hymenoptera, Diptera, Coleoptera and Ortoptera were the most representative orders of invertebrates collected, corresponding to $42.6 \%, 14.4 \%, 10.5 \%, 7.7 \%$ and $6.0 \%$ of sampled specimens, respectively; while Seriata, Neuroptera, Trichoptera, Haplotaxida, Scorpiones, Embioptera, Dermaptera and Psocoptera were the less representative taxa in the survey area, with only few specimens collected.

Other insect orders were less representative in the area, including Lepidoptera, an important taxon of pollinating agents, with only 35 samples collected in the period. Trichoptera had one individual collected in the $5 \mathrm{~m}$ distance; Neuroptera only one individual collected in the 15 $\mathrm{m}$ distance and seven Dermaptera specimens were collected exclusively $30 \mathrm{~m}$ from the reservoir.

Table 2 - Richness and abundance of invertebrate orders captured with pitfall traps from December 2010 to June 2011 at different distances from the maximum limit of the small hydroelectric station reservoir of Flor do Sertão, Brazil

\begin{tabular}{lrrrr}
\hline Invertebrate & 5 meters & 15 meters & 30 meters & Total \\
\hline Diptera & 545 & 413 & 514 & 1,472 \\
Collembola & 2,240 & 1,685 & 2,066 & 5,991 \\
Hemiptera & 285 & 288 & 246 & 819 \\
Coleoptera & 411 & 299 & 378 & 1,088 \\
Ortoptera & 308 & 232 & 299 & 839 \\
Hymenoptera & 467 & 556 & 1,006 & 2,029 \\
Araneae & 235 & 211 & 255 & 701 \\
Plecoptera & 88 & 109 & 110 & 307 \\
Thysanoptera & 51 & 56 & 39 & 146 \\
Acarina & 87 & 118 & 126 & 331
\end{tabular}

\begin{tabular}{lrrrr}
\hline Invertebrate & 5 meters & 15 meters & 30 meters & Total \\
\hline Blattodea & 15 & 7 & 8 & 30 \\
Trichoptera & 1 & 0 & 0 & 1 \\
Psocoptera & 6 & 4 & 2 & 12 \\
Pulmonata & 14 & 33 & 30 & 77 \\
Isopoda & 16 & 19 & 25 & 60 \\
Haplotaxida & 0 & 1 & 2 & 3 \\
Lepidoptera & 13 & 10 & 12 & 35 \\
Opiliones & 29 & 39 & 45 & 113 \\
Embioptera & 3 & 1 & 3 & 7 \\
Neuroptera & 0 & 1 & 0 & 1 \\
Dermaptera & 0 & 0 & 7 & 7 \\
Seriata & 0 & 1 & 0 & 1 \\
Scorpiones & 0 & 2 & 2 & 4 \\
Total & 4,814 & 4,085 & 5,175 & 14,074 \\
\hline
\end{tabular}

The analyses regarding size and sample coverage presented few differences in invertebrate diversity between the assessed distances (Figure $2 \mathrm{a}$ and $2 \mathrm{~b}$ ). Diversity tends to be higher at 15 and $30 \mathrm{~m}$ from the flooded region; however, the values of richness $(\mathrm{q}=\mathrm{O})$ and diversity of common groups $(q=1)$ are very similar for all distances. Considering the diversity of dominant groups $(\mathrm{q}=2)$, the distance of $5 \mathrm{~m}$ presented a lower value in comparison to the 15 and $30 \mathrm{~m}$ distances (Figure $3^{a}$ and $3 b$ ). The rarefaction curves tended to an asymptote covering the richness of invertebrate groups by the three sampling distances (Figure 2c). 


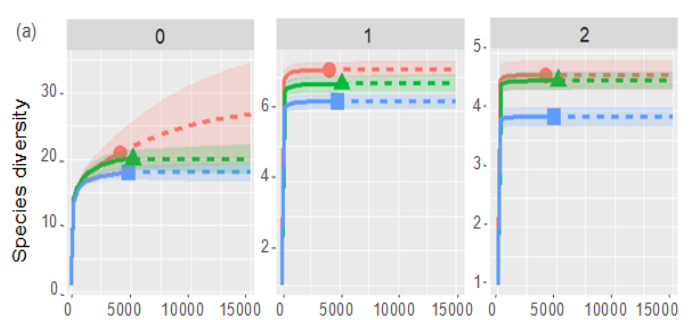

Number of individuals

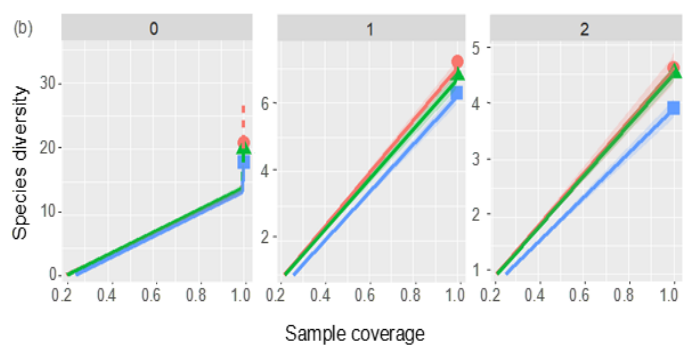

Sample coverage

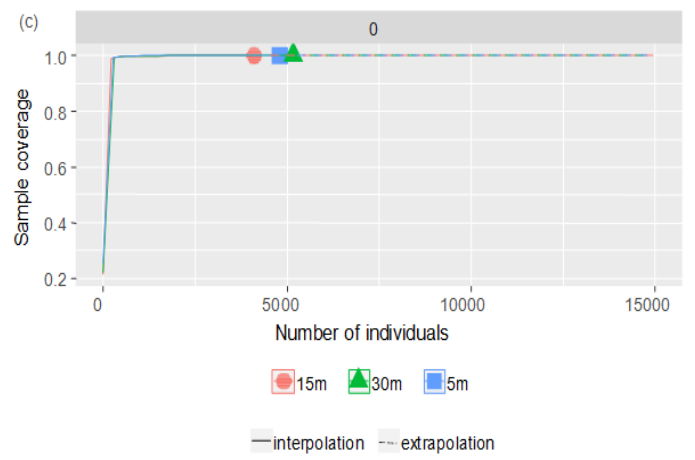

Figure 2 - Rarefaction and extrapolation of edaphic invertebrate diversity at different distances from the maximum limit of the hydroelectric station reservoir of Flor do Sertão, Brazil, for Hill numbers of order ( $q=0$ ) (left panel), $q=1$ (central panel) and $\mathrm{q}=\mathbf{2}$ (right panel), based on sample size (a) and sample coverage (b). Graph (c) represents sample coverage curves based on numbers of individuals. Confidence interval of $95 \%$ (shaded region) obtained by the bootstrap method.

The diversity dynamics of edaphic invertebrates captured with pitfall traps from December 2010 to June 2011 at different distances from the reservoir can be observed in Figure 3. There is a decreasing trend in diversity based on the Shannon exponential, with a strong decline in June (Figure 3a). The diversity based on the inverse Simpson index remained almost stable but increased in June (Figure $3 \mathrm{~b}$ ). In addition, some differences were observed between the studied distances.
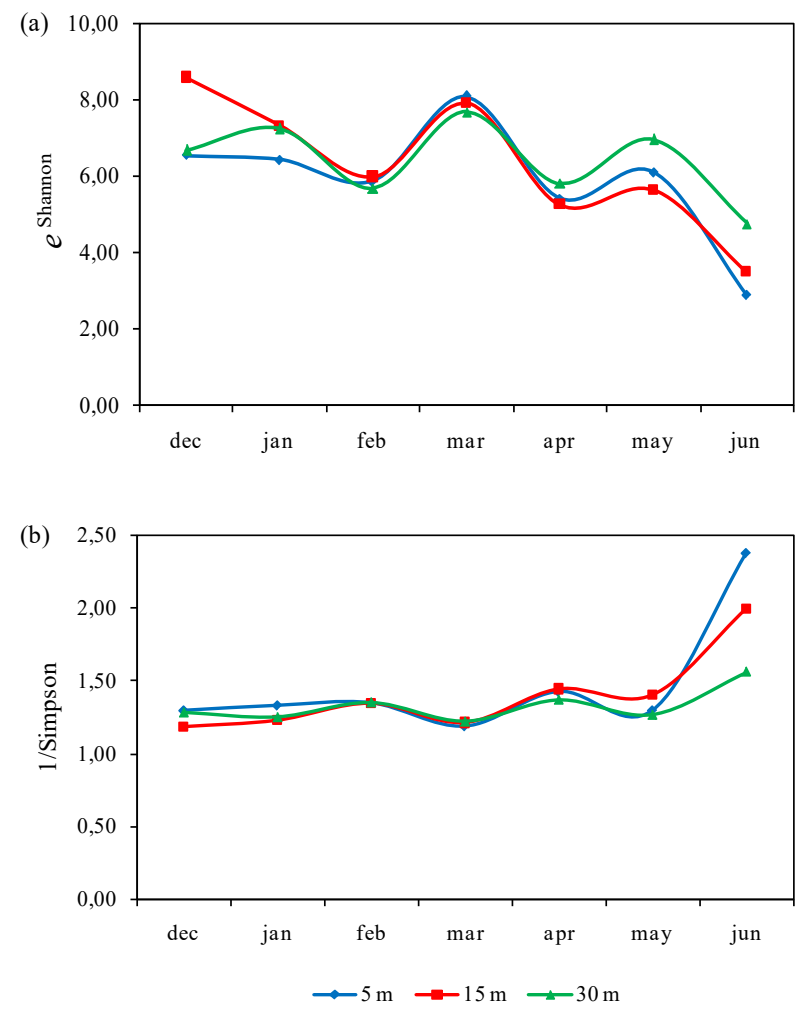

Figure 3 - Diversity of edaphic invertebrates collected at different distances from the reservoir. (a) $e^{\text {Shannon; }}$ (b) 1 /Simpson.

In general, the diversity of soil invertebrates showed almost no correlation with rainfall. However, there was a high correlation with the maximum, minimum and average temperatures, being positive for the Shannon exponential and negative for the inverse Simpson index (Table 3 ). 
Table 3 - Correlation values between climatic variables and diversity based on the Shannon index exponential and inverse Simpson index for the Flor do Sertão hydroelectric, Brazil

\begin{tabular}{lll}
\hline & $e^{\text {Shannon }}$ & 1/Simpson \\
\hline Pluviosity & 0.13 & 0.05 \\
Tmin & 0.64 & -0.76 \\
Tmax & 0.69 & -0.73 \\
Tmean & 0.71 & -0.77 \\
\hline
\end{tabular}

\section{DISCUSSION}

Observing the assemblage composition of thesoil fauna is a way to understand soil functioning and the bioindicators of its quality, revealing their respective area conditions ${ }^{22}$. Collembola was the most abundant group collected in all sites. This invertebrate is responsive to disturbances and considered an efficient bioindicator of soil quality, playing a functional role in organic matter dynamics ${ }^{30,31}$.

Arthropods have a close relationship with their habitat and are essential bioindicators in environmental studies, occupying a wide variety of niches and integrating several ecological processes $^{32}$. Insects (Arthropod: Insecta) were the most abundant taxon collected, with samples from 16 orders. Hymenoptera, Diptera, Orthoptera, Coleoptera and Hemiptera orders were found in greater number in the summer, dwindling in fall and winter. Collembola presented a similar distribution throughout the seasons, and thus there likely were no disturbances in the environment, such as changes in organic matter. According to Wink et al.33, the most important soil bioindicators are insects, because they are the most diverse group and great indicators of environmental impact levels.

In addition to insects, arachnids (Araneae, Acarina, Opiliones, Scorpiones) play an important role in ecosystem processes and were another representative taxon in our collections. Spiders (Araneae) are sensitive animals and important predators in terrestrial ecosystems, and are understood as bioindicators for environmental diagnosis ${ }^{34,35}$. Soil mites (Acarina) directly influence soil fertility, stimulating microbial activity and transporting decomposing organic matter for deeper levels of the soil profile. Furthermore, they are one of the most abundant organisms of the soil mesofauna, acting as predators and being involved in the cycling of organic matter ${ }^{36}$. Isopods (Arthropod: Crustacean) were also collected in the survey area. These terrestrial crustacean are sensitive and generally respond negatively to the loss of habitat and resources, being more abundant in natural ecosystems ${ }^{37,38}$, participating in nutrient cycling and fragmentation of the available litter ${ }^{39}$.

Pulmonata was the only taxon from the Mollusk phylum (Gastropod), with 77 samples collected. Gastropods can be herbivores, by feeding on algae, scavengers or carnivores, requiring environments with humidity to survive and can indicate disturbances given they act in food chains and nutrient cycles mainly in humid and aquatic ecosystems ${ }^{40}$. Other less expressive order was Haplotaxida (Annelida: Oligochaeta), with only 3 individuals collected in this study. These organisms are important representatives of freshwater benthic fauna. Many species of oligochaetes live buried in sediment ingesting organic matter colonized by microorganisms, a challenge for pitfall trap collection. According to Lavelle et al.4, worms act in the maintenance of soil fertility and ecosystem quality, indicating the trophic state of the environment: as the amount of organic matter available in the environment increases, there is an expressive increase in the 
abundance of the population of these animals in lakes and watercourses.

Measures of diversity and similarity are important tools for evaluating changes in species composition along environmental gradients ${ }^{41}$. Although there is a high diversity of edaphic invertebrates in the area, the Hill numbers analysis showed no significant differences between the different collection distances. Hill numbers characterize species diversity, and assemblage ranking and comparing depend on the choice of q, being increasingly used nowadays ${ }^{41-43}$. Besides, comparisons between diversities of different assemblages proved effective, according to Jost ${ }^{41}$.

Comparing edaphic invertebrates from different distances of the reservoir revealed that they may also display seasonal behavior and exploit favorable soil conditions, with their development, reproduction and behavior directly influenced by several abiotic factors ${ }^{14}$. However, there is a low correlation between total diversity and pluviosity. We could observe high pluviosity during December 2010 and January 2011, resulting in an increase in the reservoir level and, consequently, higher humidity in the $5 \mathrm{~m}$ distance. In contrast, greater biodiversity was observed in the distance of $15 \mathrm{~m}$ during these months. This fact probably caused the arthropods to migrate looking for an environment more suitable to their development, distancing themselves from the reservoir.

The positive correlation with temperature indicates that, when it increases, the diversity of common invertebrates also increases, and vice versa. This fact is corroborated by the decreasing diversity trend based on the Shannon exponential throughout the collection period (Figure 3a). As winter approached by June, the temperature began to decrease, and consequently, the diversity of edaphic invertebrates decreased ${ }^{44}$. In contrast, lower temperatures favors dominant individuals of soil invertebrates. Thus, there is a diversity increase based on the inverse Simpson index during June, which was the coldest month (Figure $3 \mathrm{~b}$ ).

Anthropogenic activities can promote fragmentation of natural systems, and homogenized habitats generally imply a smaller variety of available resources, drastically leading to reduced diversity in most taxonomic groups ${ }^{8,45}$. Based on the obtained results, reasonable biological diversity of edaphic invertebrates in the reservoir area was verified. Considering only the invertebrate sampling analyzed in the area during the study period, activity in the hydroelectric apparently did not have a significant impact on the local invertebrate fauna. However, we cannot conclude this with certainty because the biodiversity of this area was not known before the hydroelectric construction, and more specific studies should be performed in order to confirm these results, as long-term monitoring is required for a better sample effort and more precise results of population dynamics over time ${ }^{46,47}$. Furthermore, vertebrate fauna was not investigated before the writing of this article. Our initial data of edaphic invertebrates are important to the local community to lead to further studies investigating these complex issues.

It is very important to mention that for this study no soil analysis was performed that showed chemical or physical parameters and thus justify the presence of certain groups of edaphic invertebrates. In addition, it should be considered that the samples were collected almost 1o years ago, that is, approximately 3 years since the beginning of the activities of the small hydroleletric power station, and that over the years, the physical and 
chemical characteristics of the soil can have been altered, as well as the invertebrate groups present in this area.

\section{CONCLUSION}

Collembola, Hymenoptera, Diptera, Coleoptera and Ortoptera were the most representative edaphic invertebrate orders sampled in the area; while Seriata, Neuroptera, Trichoptera, Haplotaxida, Scorpiones, Embioptera, Dermaptera and Psocoptera were the less representative taxa collected. No significant differences were detected on edaphic invertebrate diversity in flooded areas surrounding the small hydroelectric power station reservoir. Furthermore, the diversity of edaphic invertebrates showed a high correlation with temperatures, and no correlation with pluviosity was detected. The high pluviosity resulted in an increase in the reservoir level and, consequently, higher humidity in the nearest distances. This probably caused the arthropods to migrate looking for an environment more suitable to their development. The positive correlation with temperatures indicates that, when it increases, the common invertebrate diversity also increases. As winter approached, the temperature began to decrease, and the diversity of edaphic invertebrates decreased.

\section{CONFLICTS OF INTEREST}

The research was developed by an academic during her MBA with no conflicts of interests.

\section{ACKNOWLEDGEMENTS}

The authors acknowledge their gratitude to the Mauê S.A. - Geradora e Fornecedora de Insumos, the management company of the small hydroelectric power station of Flor do SertãoSC, Brazil, in particular to the technical director João Carlos Floss for authorization and consent to perform the study in the area. In addition, thanks to Wilson and Eduardo Luiz Scopel for their field support during the entire experiment, essential for this investigation, which is the final paper of the MBA of the first author in Environmental Management with an emphasis on Licensing, Auditing and Environmental Expertise.

\section{REFERENCES}

1. Silva Jr NJ, Silva HLR, Costa MC, Buononato MA, Tonial MLS, Ribeiro RS, et al. Avaliação preliminar da fauna silvestre terrestre do vale do rio Caiapó, Goiás: Implicações para a conservação da biodiversidade regional. Rev EVS - Revista Ciências Ambient e Saúde. 2007; 34(6):1057-94.

2. Leão LL. Considerações sobre impactos socioambientais de Pequenas Centrais Hidrelétricas (PCHs): modelagem e análise [Dissertação]. Brasília: Universidade de Brasília; 2008.

3. Aneel. Levantamento de estudos de inventário aprovados em 2006 revela potencial hidrelétrico de 6 mil megawatts. Informativo semanal. 2007; 254.

4. Lavelle P, Dangerfield M, Fragoso C, Eschenbrenner V, Lopez-Hernandez D, Pashanasi B, et al. The relationship between soil macrofauna and tropical soil fertility. Biol Manag Trop soil Fertil. 1994;137-69. 
5. Lavelle P. Diversity of soil fauna and ecosystem function. Biol Int. 1996;33(3.16).

6. Nunes LAPL, Araújo Filho JA, Queiroz Menezes RÍ. Diversidade da fauna edáfica em solos submetidos a diferentes sistemas de manejo no semi-árido nordestino. Sci Agrar. 2009;10(1):43-9.

7. Losey JE, Vaughan M. The economic value of ecological services provided by insects. Bioscience. 2006;56(4):311-23.

8. Dirzo R, Young HS, Galetti M, Ceballos G, Isaac NJB, Collen B. Defaunation in the anthropocene. Science (80- ). 2014;345(6195):401-6.

9. Berude M, Galote JK, Pinto PH, Amaral A. A mesofauna do solo e sua importância como bioindicadora. Enciclopédia Biosf. 2015;11(22).

10. Leivas FWT, Carneiro E. Utilizando os hexápodes (Arthropoda, Hexapoda) como bioindicadores na biologia da conservação: avanços e perspectivas. Estud Biol. 2012;34(83).

11. Barros YJ, Melo VF, Sautter KD, Buschle B, Oliveira EB, Azevedo JCR, et al. Indicadores de qualidade de solos de área de mineração e metalurgia de chumbo: II-Mesofauna e plantas. Rev Bras Ciência do Solo. 2010;34:1413-26.

12. Oliveira MA, Gomes CFF, Pires EM, Marinho CGS, Della Lucia TMC. Bioindicadores ambientais: insetos como um instrumento desta avaliação. Rev Ceres. 2014;61:800-7.

13. Rovedder APM, Eltz FLF, Drescher MS, Schenato RB, Antoniolli ZI. Organismos edáficos como bioindicadores da recuperação de solos degradados por arenização no Bioma Pampa. Ciência Rural. 2009;39:1051-58.

14. Silveira Neto S, Monteiro RC, Zucchi RA, De Moraes RCB. Uso da análise faunística de insetos na avaliação do impacto ambiental. Sci agrícola. 1995;52:9-15.

15. Fahrig L. Effects of habitat fragmentation on biodiversity. Annu Rev Ecol Evol Syst. 2003;34(1):487515 .

16. Carvalho CJB. Padrões de endemismos e a conservação da biodiversidade. Megadiversidade. 2009;5(1-2):77-86.

17. Niebuhr BBS, Wosniack ME, Santos MC, Raposo EP, Viswanathan GM, Da Luz MGE, et al. Survival in patchy landscapes: the interplay between dispersal, habitat loss and fragmentation. Sci Rep. 2015;5(1):1-10. 
18. Jost L, DeVries P, Walla T, Greeney H, Chao A, Ricotta C. Partitioning diversity for conservation analyses. Divers Distrib. 2010;16(1):65-76.

19. Cherem JJ. Caracterização do empreendimento e dos estudos faunísticos. In: Cherem JJ, Kammers M, editores. A fauna das áreas de influência da Usina Hidrelétrica Quebra Queixo. Erechim, RS: Habilis; 2008. p. 192.

20. Coelho SJ, Pereira JAA. A paisagem na área de influência da Usina Hidrelétrica do Funil (UHE-FUNIL), percebida através do EIA-RIMA. Paisag e Ambient. 2010;(28):133-48.

21. Alvares CA, Stape JL, Sentelhas PC, Gonçalves JLM, Sparovek G. Köppen's climate classification map for Brazil. Meteorol Zeitschrift. 2013;22(6):711-28.

22. Aquino AM, Aguiar-Menezes EL, Queiroz JM. Recomendações para coleta de artrópodes terrestres por armadilhas de queda (“ Pitfall-Traps”). Embrapa Agrobiol Técnica; 2006.

23. Borror DJ, Delong DM. Introdução ao estudo dos insetos. São Paulo: Edgard Blücher; 1988.

24. Amaral ACZ, Rizzo AE, Arruda EP. Manual de identificação dos invertebrados marinhos da região sudeste-sul do Brasil. São Paulo: EdUSP; 2006. vol. 1.

25. Araújo EA, Ribeiro GA. Impactos do fogo sobre a entomofauna do solo em ecossistemas florestais. Nat Desenvolv. 2005;1(1):75-85.

26. Hsieh TC, Ma KH, Chao A. iNEXT: an R package for rarefaction and extrapolation of species diversity (H ill numbers). Methods Ecol Evol. 2016;7(12):1451-56.

27. Chao A, Gotelli NJ, Hsieh TC, Sander EL, Ma KH, Colwell RK, et al. Rarefaction and extrapolation with Hill numbers: a framework for sampling and estimation in species diversity studies. Ecol Monogr. 2014;84(1):45-67.

28. Team RC. R: A language and environment for statistical computing. 2013.

29. Hammer Ø, Harper DAT, Ryan PD. PAST-palaeontological statistics, ver. 1.89. Palaeontol electron. 2001;4(1):1-9.

30. Cassagne N, Gauquelin T, Bal-Serin M-C, Gers C. Endemic collembola, privileged bioindicators of forest management. Pedobiologia (Jena). 2006;50(2):127-34.

31. Baretta D, Ferreira CS, Sousa JP, Cardoso EJBN. Colêmbolos (Hexapoda: Collembola) como bioindicadores de qualidade do solo em áreas com araucaria angustifolia. Rev Bras Ciência do Solo. 2008;32:2693-99. 
32. Martins CF, Zanella FCV, Quinet YP. Diversidade de artrópodes em áreas prioritárias para conservação da Caatinga. In: Araújo FS, Rodal MJN, Barbosa MRV, editores. Análise das variações da biodiversidade do bioma caatinga: suporte a estratégias regionais de conservação. Brasília: Ministério do Meio Ambiente; 2005. p. 446.

33. Wink C, Guedes JVC, Fagundes CK, Rovedder AP. Insetos edáficos como indicadores da qualidade ambiental. Rev Ciências Agroveterinárias. 2005;4(1):60-71.

34. Dias MFR, Brescovit AD, Menezes M. Aranhas de solo (Arachnida: Araneae) em diferentes fragmentos florestais no sul da Bahia, Brasil. Biota Neotrop. 2005;5:141-50.

35. Prieto-Benítez S, Méndez M. Effects of land management on the abundance and richness of spiders (Araneae): a meta-analysis. Biol Conserv. 2011;144(2):683-91.

36. Pereira RC, Albanez JM, Mamédio IMP. Diversidade da meso e macrofauna edáfica em diferentes sistemas de manejo de uso do solo em Cruz das Almas-BA. Magistra. 2012;24(2):63-76.

37. Nakamura A, Proctor H, Catterall CP. Using soil and litter arthropods to assess the state of rainforest restoration. Ecol Manag Restor. 2003;4:S20-8.

38. Riggins JJ, Davis CA, Hoback WW. Biodiversity of belowground invertebrates as an indicator of wet meadow restoration success (Platte River, Nebraska). Restor Ecol. 2009;17(4):495-505.

39. Quadros AF, Araujo PB. An assemblage of terrestrial isopods (Crustacea) in southern Brazil and its contribution to leaf litter processing. Rev Bras Zool. 2008;25:58-66.

40. Silva GT. Diversidade de Mollusca nos costões rochosos da Praia da Ribanceira, município de Imbituba, Santa Catarina, Brasil. Santa Catarina: Unesc; 2008.

41. Jost L. Entropy and diversity. Oikos. 2006;113(2):363-75.

42. Hill MO. Diversity and evenness: a unifying notation and its consequences. Ecology. 1973;54(2):427-32.

43. Chiu C-H, Chao A. Distance-based functional diversity measures and their decomposition: a framework based on hill numbers. PLoS One. 2014;9(7):e10oo14.

44. Sinclair BJ, Vernon P, Klok CJ, Chown SL. Insects at low temperatures: an ecological perspective. Trends Ecol Evol. 2003;18(5):257-62. 
45. Botteon VW. Perspectivas de uso de insetos bioindicadores ambientais em trabalhos periciais. Brazilian J Forensic Sci Med Law Bioeth. 2016;5(4):383-401.

46. Magurran AE, Baillie SR, Buckland ST, Dick JM, Elston DA, Scott EM, et al. Long-term datasets in biodiversity research and monitoring: assessing change in ecological communities through time. Trends Ecol Evol. 2010;25(10):574-82.

47. Chiquetto-Machado PI, Amorim FW, Duarte M. Long-term stability of the hawkmoth fauna (Lepidoptera, Sphingidae) in a protected area of Brazilian Atlantic Rain Forest. J Insect Conserv. 2018;22(2):277-86. 
